\author{
Marquette University \\ e-Publications@Marquette
}

History Faculty Research and Publications

History, Department of

2006

\title{
The Formative Influence of French Colonialism on the Life and Thought of Malek Bennabi (Malik bn Nabi)
}

Phillip Chiviges Naylor

Marquette University, phillip.naylor@marquette.edu

Follow this and additional works at: https://epublications.marquette.edu/hist_fac

Part of the Intellectual History Commons, Islamic World and Near East History Commons, Political History Commons, and the Race, Ethnicity and Post-Colonial Studies Commons

\section{Recommended Citation}

Naylor, Phillip Chiviges, "The Formative Influence of French Colonialism on the Life and Thought of Malek Bennabi (Malik bn Nabi)" (2006). History Faculty Research and Publications. 1.

https://epublications.marquette.edu/hist_fac/1 


\title{
The Formative Influence OF French Colonialism on THE LIFE AND THOUght OF Malek Bennabi (MaliK bN Nabi)
}

\author{
Phillip C. Naylor
}

Malek Bennabi (1905-73) fut un intellectuel algérien de premier rang. Cet article étudie l'effet du colonialisme sur sa vie et ses idées. L'étude considère ses livres et offre une comparaison entre Bennabi et Frantz Fanon. Bennabi montre qu'il n'était pas " colonisable " à cause de sa formation et sa conscience historique.

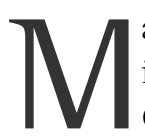
alek Bennabi ${ }^{1}$ (1905-73) ranks as one of the most significant intellectuals in modern Algerian and Islamic history. Born in Constantine, Algeria, he received French and Arabic educations. He was trained as a civil engineer, but Bennabi's reputation arose from his religious and philosophical writings supporting Islah or Islamic reform. He devoted his life toward raising and revitalizing not only an Algerian, but also a wider Muslim social and historical consciousness.

I first realized Bennabi's significance in the writing of the late David C. Gordon, a prominent member of the French Colonial Historical Society. ${ }^{2}$ Studying Bennabi's works deepened my appreciation of his fertile and expansive intellect. Although he was clearly linked to Islam's reformist and modernist movements, Bennabi was a man of acute, independent critical judgment reinforced by a vast erudition. Bennabi's extensive interests included the study of history, culture, religion, science, technology, sociology, psychology, and philosophy. Furthermore, he was politically committed-less to a party or person, but to Islam, the developing world, and, of course, Algeria. His Islamism pursued an objective- to renew, reform, and

Phillip C. Naylor is Associate Professor of History at Marquette University in Milwaukee, Wisconsin.

(C) French Colonial History

Vol. 7, 2006, pp. 129-142

ISSN 1539-3402 
restore Islam as the central dynamic in Muslim society. Vartan Gregorian in his general study Islam: A Mosaic, Not a Monolith viewed Islamism as "liberation politics." ${ }^{3}$ To Bennabi, Islam was a vehicle not only for political but also social, cultural, and intellectual liberation. Bennabi also considered the age of decolonization a momentous, global historical opportunity. This article presents a general exploratory overview of Bennabis life and thought, with particular attention given to the formative role of French colonialism and Algerian and Third World decolonization.

\section{BENNABI'S EDUCATION}

Bennabi's family had the means to provide him with a French as well as Qur'anic education at Tébessa and his native Constantine. ${ }^{4}$ He eventually continued his studies in Paris. His family also offered him invaluable lessons-memories of protests against French colonialism. Bennabi's great-grandmother's family moved from Constantine to Tunis when the French took over the city in 1837 . They eventually reached Mecca before returning to Algeria years later. He learned about his family history from his grandmother, who instilled in Bennabi a sense of honor and history. His paternal grandfather was among those Algerians who shunned French colonial and cultural pretensions and left for Tripoli in 1908. ${ }^{5}$

In his autobiography, Bennabi describes his initial difficulties at Qur'anic and French schools. His relatives eventually pulled Bennabi from his Qur'anic school. As Bennabi matured, his attitude toward education improved markedly. ${ }^{6}$ His French teachers were impressed with him and he with them, despite systemic colonial discrimination, which he and others suffered as "indigènes." His class promotions as well as the support of his family allowed Bennabi to continue his education in his beloved Constantine. Despite colonialism, Bennabi found Constantine's French as well as Arab urban character stimulating. At this time, he resumed Islamic studies at a madrasa taught by Shaykh Abdelmadjid, a progressive and persuasive 'alim (religious teacher/leader). The shaykh instilled the values of the emerging Nahda or Renaissance movement, which insisted that Islam and modernity were compatible. Concurrently, Bennabi also sought to improve his Arabic reading and composition. He would begin the day at the madrasa and then hurry to his French school, where Monsieur Georges Martin introduced the increasingly inquisitive Bennabi to a constellation of writers.

Throughout his life- and this is quite exceptional regarding the colonial elite-Bennabi had no problems crossing back and forth over this 
bridge spanning Arabic/Islamic and French/secular cultures. ${ }^{7}$ He was not torn or suspended between cultures (sans complexe). The "psychoexistential complex"8 that Frantz Fanon (1925-61) observed and analyzed among the colonized in the Antilles and later Algeria was irrelevant to Bennabi. In particular, his historicity (especially inculcated by his family) prevented an inferiority or identity problem. In addition, Bennabi was fascinated by his native city's legacy, or as he put it in his autobiography, "Constantine of the [Ottoman] beys." He also noted Tébessa's Byzantine walls, which dated from the sixth century. He appreciated history as a dynamic force and concluded that contemporary conditions (and miseries) were provisional.

Nevertheless, Bennabi's realities were difficult and distressing. He witnessed the inherent discrimination and dehumanization of colonialism. World War I Muslim veterans ("heroes") continued to wear their uniforms years after the conflict while they sank into clochardisation or destitution. Fanon viewed colonialism as Manichaean-marked by spatial and economic dualities. To Bennabi, colonialism was a polarizing force, especially in education. He watched European lycéens and imagined their futures in law, medicine, and higher education-careers usually unattainable for indigènes. He reflected: "Me, I am condemned to be an adel ['adl: juristic assistant assigned to a qadi (Fr. caïd)]." Colonialism restricted opportunities and was a frustrating force, yet paradoxically, colonialism also opened the world to Bennabi and other privileged and gifted indigènes. While he read (and enjoyed) the Orientalist imagery of René Chateaubriand and Alphonse de Lamartine, Pierre Loti, and Claude Farrère, correctives were provided by Jamal al-Din al-Afghani and Muhammad Abduh, principal leaders of the Islamic Modernist movement. Bennabi points out that the Nahda movement, usually identified with al-Afghani and Abduh, was already a grass-roots movement in the Maghrib (especially in Tunisia). Constantine (and Tlemcen in the west) was especially engaged. Indeed, Bennabi's autobiography is particularly valuable in describing the currents of reformist Islamic discourse at that time. ${ }^{10}$ Furthermore, Bennabi's growing interest in civilization studies led him to the poetry of India's Rabindranath Tagore. Tagore's lyricism reinforced the idea that genius was not limited to Western Europe. Bennabi wrote that Tagore helped "spring the lock of colonialism on my spirit."11

Bennabi also began reading al-Iqdam of Emir Khaled, the grandson of the revered Abd al-Qadir. ${ }^{12}$ Emir Khaled went beyond the prudent protests of the Jeunes Algériens and called for France to live up to its ideals, especially regarding the recognition and assimilation of évolués. 
Khaled's audacity resulted in his exile to Syria, reminiscent of his grandfather. Bennabi became politically aware rather than aligned; instead, Islam was becoming his "central preoccupation."13

After graduating from high school, Bennabi went to France briefly and lived the life of an emigrant worker, holding several unskilled-labor jobs, including stacking beer-bottle cases. He despised how Algerian immigrant workers were exploited. ${ }^{14}$ Returning to Algeria, he became an 'adl in Aflou near Oran. He found this work, too, to be unfulfilling. He decided to continue his studies. With the support of his family, he returned to France in 1930.

While studying science and engineering at the École spéciale de mécanique et d'électricité (Sudria), Bennabi joined a Catholic student social club (l'Union chrétienne des jeunes gens de Paris de la rue Trévise [Paris 9]), where he found stimulating religious and philosophical discourse. He also met his first wife, who converted to Islam and took the name Khadija. As Allan Cristelow perceived, "His experience in the ... club allowed him to see Christians outside of the colonial context. For Bennabi, dialogue between Islam and other civilizations was possible, indeed highly desirable, but such dialogue could not take place within an asymmetrical colonial framework."15

Meanwhile, Bennabi's philosophical and religious thinking deepened. His training in this area was informal but vigorous and exciting. In the 1930s, the Maghribi community in Paris was vibrant and included the nationalists Habib Bourguiba of Tunisia and Muhammad al-Fasi of Morocco. Bennabi was involved in the Maghribi student groups and affairs. He became secretary-general of the Association des étudiants musulmans d'Afrique du Nord (AEMAN) in 1932. He also spent summers in Algeria, where he heard Bashir al-Ibrahimi and befriended Tayyib al-Uqbi, prominent members of Shaykh Abd al-Hamid Ben Badis's Association des uléma musulmans algériens (AUMA). However, he became disillusioned with the ulama's political dealings with Messali Hajj and Ferhat Abbas. In the second volume of his memoirs, Messali is castigated for his demagogy. ${ }^{16}$ Bennabi especially targeted Abbas's identification with assimilation. He found Abbas's contention that "I am France" ridiculous. Bennabi briefly led the Cercle culturel du Congrès musulman algérien in 1937 and was appalled by the Algerian political elite's disregard for their countrymen, the immigrant workers toiling in France. Throughout his adult life, Bennabi would play this role of the agoniste. There were few Algerian leaders during the colonial and postcolonial 
periods whom he deeply admired. His memoirs end after he completes his studies in France. Bennabi's activities during World War II are unknown; however, after World War II, Bennabi published several important works, which earned him a reputation as one of the most eminent Maghribi intellectuals since Ibn Khaldun.

\section{A Brief Consideration of BenNabi's Works}

The first work was Le phénomène coranique: Essai d'une théorie sur le Coran. In this book, Bennabi evinces his concern regarding young Muslim scholars, especially those in Algeria, who have to seek foreign authors, imbued with "Cartesian" methodologies to satisfy intellectual needs, especially regarding Islam. ${ }^{17}$ In particular, Bennabi is concerned about the interpretation of Islam by European Orientalists. Predating Edward Saïd, Bennabi views Orientalism as threatening Muslims' "historical orientation."18 In turn, Bennabi introduces a brilliant, modern, multidisciplinary exegesis. Refuting rationalist and materialist positions and reductions, Bennabi views religious consideration and contemplation as intrinsic to human thought and consciousness. He explores and compares prophetic traditions. His study of the Prophet Muhammad provides biographical and psychological analyses. He examines revelations side by side and verse by verse, specifically the story of Joseph as revealed in the Hebrew Bible and the Qur'an. To Mohamed el-Tahir el-Mesawi: "This book stands as one of the most mature efforts of Muslim intellectual engagement with the secular premises and materialistic scientific world-view of modernity." 19 Nevertheless, el-Mesawi reminds us: "What is of the utmost concern for Bennabi is the conception of reason and science as utterly antithetical to religion and revelation." 20 In a theme common to all his publications, Bennabi believed in the virtues of the rational intellect and saw it as compatible with spirituality. This book was certainly meant to raise the consciousness of Muslims and persuade them to pursue a religious reexamination and revival. However, it also aimed at the non-Muslim audience wanting to acquire a better understanding of Islam. Le phénomène coranique is an ecumenical work. Indeed, it was dedicated to his parents, his "dear friend and mentor" Mohammed Ben Sai (Sa'i), ${ }^{21}$ and his former teacher Georges Martin, "who showed me that man has his brothers and his enemies among all peoples and all races."

Bennabi's next major work was a surprising one-a novel, Lebbeik: Pèlerinage de pauvres (1948). It recounts the redemptive qualities of Islam: 
an alcoholic rejects his past and performs the hajj, taking in tow an orphan. Although it is a novel about Islam, Allan Cristelow perceives the book as a characteristically French work, given its "exaggerated didactic spirit which the French seem to favour in works of moral education."22

Bennabi then published the provocative Discours sur les conditions de la Renaissance algérienne (1949). In this controversial book, Bennabi analyzes Algerian society and the wider Muslim world and its potential to achieve a Renaissance, not only in the Islamic but also secular context. Again, the importance of becoming historically conscious is crucial. Bennabi writes: "Peoples who sleep have no history but nightmares or dreams." He cites a Qur'anic imperative: "God does not change the state of a people until it first has changed the state of its soul." This means "repreaching Islam to Muslims," using the Salafi as guidelines. ${ }^{23}$ Bennabi implies that the AUMA had succumbed to "political opportunism" in relation to the short-lived Congrès musulman algérien of 1936, ${ }^{24}$ but he still admires the ulama's Islahism. In addition, he severely criticizes Algerian intellectuals for their inauthenticity. ${ }^{25}$

It is in Discours that Bennabi introduces one of his seminal and memorable statements. He writes: "Colonization is not a capricious policy, although it can appear so, but a necessity of history. One does not cease to be colonized until one ceases to be colonizable: it is an immutable law."26 "Colonizability" is viewed as a determinant of Algeria's and the Muslim world's decadent condition. Nevertheless, Bennabi believes that "the Muslim world is being reborn," but adds: "The Algerian people, in particular, must be reborn." 27 Bennabi places these rebirths in the context of Nietzsche's idea of "the eternal return," a cyclical philosophy of history that also evokes Ibn Khaldun (as well as metahistorians Arnold Toynbee and Oswald Spengler). ${ }^{28}$

In many ways, his next book, Vocation de l'Islam, resumes the positions he took in Discours sur les conditions, but the narrative is much more analytical. (It was written immediately after Discours but appeared in 1954.) This book, published by Seuil in Paris before the outbreak of the War of Liberation, brought Bennabi before a wider audience-namely the colonizers. Bennabi begins by criticizing the renowned British Orientalist H. A. R. Gibb and his book Modern Trends of Islam. In his work, Gibb attributed Muslim humanism to European influences. In turn, Bennabi presents two autochthonous humanists to refute Gibb: the astronomer Abu-l-Wafa and Ibn Khaldun. Furthermore, Bennabi questions European humanism, since it had also produced colonialism. ${ }^{29}$ 
Returning to his interest in the development and decline of civilizations (especially Islamic civilization), Bennabi introduces an important term. "The era of decadence," Bennabi explains, "began with the PostAlmohadean man." 30 Unlike the "man of Muslim civilization," postAlmohadean man has lost his curiosity, his inquiry, and his historical and social consciousness. Instead, he is resigned to intellectual and moral torpor. While appreciating the stimulating effort of the Islamic Modernists, Bennabi believes they have failed to "transform the Muslim soul" or to realize Islam's "social function." 31 He contends that post-Almohadean man's presence pervades Algeria and the Muslim world.

Bennabi then reiterates and elaborates upon one of his most important critical observations. The success that Europeans experienced in taking over Muslim lands was expedited by post-Almohadean man's "colonizability." Over the centuries, post-Almohadean Muslims made themselves "colonizable" by their moral weakness. Indeed, Bennabi also considered the colonized as post-Almohadeans remaining "colonizable."32

Two years after the outbreak of the War of Liberation, Bennabi moved to Egypt. ${ }^{33}$ Ahmed Ben Bella and Mohammed Khider, Front de libération nationale (FLN) "externals," welcomed Bennabi. Nevertheless, Bennabi's political and intellectual independence, and especially his critical mind, also created friction between him and the Algerian nationalist elite. In the meantime, Bennabi became close with Gamal Abdel Nasser and Anwar Sadat. After the Bandung Conference (April 1955), Bennabi published the book Afro-Asiatisme (under the auspices of the Egyptian government). In this work, Bennabi views the emerging Third World as an opportunity for religious and moral renewal on an "ecumenical" level. The moral authority of the Third World deeply impressed Bennabi, especially its emphasis on "neutrality," which he considered "the political expression of non-violence." 34 Bennabi's global perspective on decolonization and the potential of the Third World naturally mirrored his intellectual breadth, and obliges a brief comparison with his contemporary who had similar interests, Frantz Fanon.

\section{Comparing Bennabi And FAnON}

It is generally assumed that Bennabi and Fanon were dissimilar. Speaking in 1964, Bennabi stated: "To speak the language of a people, one must share its convictions. [But] Fanon was an atheist." 35 Allan Christelow considered the two men as opposites. Yet, their ideas are not strictly binary. 
Bennabi and Fanon were extraordinarily engaged and courageous intellectuals. They shared a deep concern for the condition of the colonized. Decolonization for both men was not only political, but psychological and existential. In Fanonist terms, Bennabi constantly sought to end (here sublimate) the "psychoexistential complex" of the postAlmohadean man. ${ }^{36}$ Certainly, they differed over means and methods of decolonization. Fanon viewed colonialism as "violence in its natural state, and it will only yield when confronted with greater violence." ${ }^{37}$ He contended that "violence is a cleansing force. It frees the native from his inferiority complex and from his despair and inaction; it makes him fearless and restores his self-respect." 38 Bennabi had argued long before, "To liberate oneself from . . colonialism, it is necessary to liberate oneself first from its cause-colonizability." 39 Decolonization was much more complex to Bennabi. Indeed, according to Bennabi, Muslims began becoming "colonizable" not in the nineteenth but the fourteenth century. Fanon blamed colonialism for devastating native culture: "Expropriation, spoliation, raids, objective murder, are matched by the sacking of cultural patterns, or at least condition such sacking. The social panorama is destructured, values are flaunted, crushed, emptied." ${ }^{40}$ To Bennabi, colonizability was not only imposed by "exterior" power, but also by the "colonizables" torpid "interior." Their decline and decadence were also self-inflicted. The result was a cultural psycho-temporal disruption. Bennabi wrote: "There is no history without culture, for a people which no longer has its culture, no longer has its history." ${ }^{11}$ This condition expedited the formulaic "colonizing coefficient": "A man multiplied by the colonizing coefficient equals an indigène." 42

Each intellectual viewed decolonization and the rise of the Third World as an exceptional period in the history of global civilization. Fanon wrote: "Decolonization . . . brings a natural rhythm into existence, introduced by new men, and with it a new language and a new humanity. Decolonization is the veritable creation of new men." 43 Fanon practically charged the Third World to begin "a new history of Man." 44 In turn, Bennabi considered the rise of the African-Asian bloc as "a new civilization," 45 and Afro-Asian man as "ecumenical era man." 46 Fanon envisioned the Third World as an arbiter between the superpowers, an ideal to which Bennabi also aspired: "The neutralism developing along the Tangiers-Jakarta axis increases the chance of co-existence along the Washington-Moscow axis and reinforces its orientation toward a definite pacification of the world." 47 
Fanon's greatest fear for the newly independent or soon-to-be-independent Third World state was neocolonialism without a program: "A program is necessary for a government which really wants to free the people politically and socially." 48 In L'afro-asiatisme, Bennabi introduced the idea of "co-colonialism," which equated with neocolonialism. It was an economic or strategic collusion between the still "colonizable," despite "liberation," and the excolonialist or neocolonialist powers or alliances. Bennabi had written before the War of Liberation: "The cohesive force necessary for Algerian society is eminently in Islam, but an Islam rethought and revitalized, in a social Islam." ${ }^{29}$ This was his program. During the war, he wrote about the general need "to discipline revolutionary forces" once independence is achieved in order "to undertake the capital task" of constructing a society. ${ }^{50}$ Despite the violent times that both men witnessed and endured, each believed in the possibility of positive human transformation.

\section{CONCLUSION}

Like Fanon, Bennabi recognized that decolonization was a process continuing into the postcolonial period. In his opinion, Algerian decolonization was incomplete, and colonizability remained a postcolonial reality. ${ }^{51}$ Bennabi returned to Algeria a year after its independence. In 1964, he was appointed the director of higher studies at the University of Algiers. Concurrently, he played an important role in establishing the Qiyam (Values) movement, which sought to instill Islamic values in the country. Bennabi continued to exhort the social Islamization of Algeria, a quest pursued until his death in October 1973.

According to Bennabi, "Historically, colonization is a regression in human history." ${ }^{2}$ Nevertheless, he perceived that "there is . . . a positive aspect of colonization, in that it liberates quiescent, inert potentialities," although he recognized that colonialism through the application of its "coefficient" also "tends to destroy those same potentialities." 53 Yet, Bennabi still criticized the colonized Muslim who does not take advantage of the "means already available . . . to raise the level of his life." By not doing this, Bennabi considers that Muslim to be afflicted with colonizability. ${ }^{54}$ These thoughts were also autobiographical. Bennabi sought to realize his manifold potentialities, despite colonialism, while recognizing and repudiating colonizability.

Unquestionably, French colonialism had a profound effect upon Bennabi, not only because of its exploitation (he resented the animus of 
being regarded as an indigène), but also because colonialism provided him with a historical context and consciousness. Although the author is not endorsing the 23 February 2005 legislation that passed the French Parliament, charging the teaching of positive aspects of colonialism, Bennabi was one of the relative few to benefit from an education in the métropole, which significantly contributed to his critical mind and erudition. Indeed, his historicity, reinforced by a supportive family, prevented Bennabi from becoming colonizable. Instead, he felt a moral obligation to rouse Muslims from their post-Almohadean stupor. Allan Christelow rightly calls Bennabi an "Islamist humanist." Yahia Zoubir respects him as a "democratic Islamist." 55 Yet, Bennabi is difficult to label given his insistent independence and multiple interests. What is certain is that Malek Bennabi's insightful words and works continue to impress and inspire.

\section{Notes}

1. Although a more accurate transliteration is Malik bn Nabi, I have used the French transliteration that usually appears in publications.

2. David C. Gordon, The Passing of French Algeria (London: Oxford University Press, 1966), 117.

3. Vartan Gregorian, Islam: A Mosaic, Not a Monolith (Washington, D.C.: Brookings Institute, 2003), 73-75.

4. It is difficult to piece together a biography of Bennabi. Although he published memoirs, they only recount his life until 1939. The memoirs are also problematic. For example, Bennabi was raised by a great-uncle and great-aunt as well as his parents. However, he does not explain why his parents asked his great-uncle and his wife to adopt him (see Malek Bennabi, Mémoires d’un témoin du siècle: Enfant [Algiers: Éditions Nationales Algériennes, 1965], 14). (Asma Rashid refers to Bennabi as a "foster-child" ["Malek Bennabi: His Life, Times and Thought," in Malek Bennabi, Islam in History and Society, trans. Asma Rashid (Islamabad, Pakistan: Islamic Research Institute, 1988), 3]). The poverty of Bennabi's family accounts for his moving from Constantine to Tébessa. When his father acquired employment in a commune mixte, the family fortunes improved significantly. His father especially encouraged Bennabi to pursue higher studies in France. One of the more comprehensive accounts of his life can be found in Fawzia Muhammad Bariun, "Malik Bennabi's Life and Theory of Civilization," Ph.D. diss., University of Michigan, 1988, 87-136. See also Sadek Sellam's biographical information online at oumma.com/article.php3?id_article $=1462$.

5. Mémoires d'un témoin, 10-11. His grandfather returned after the Italians invaded Tripolitania in 1911.

6. Bennabi confesses an infatuation with "Mme Buil," who recognized Bennabi's intellect (ibid., 24). 
7. As Professor Jeremy Rich pointed out in his commentary of the paper presented at the Wolfville Conference, Léopold Sédar Senghor would be another example of an elite with the ability to bridge cultures.

8. Frantz Fanon, Black Skin, White Masks, trans. Charles Lam Markmann (New York: Grove Press, 1967), 11-12.

9. Mémoires, 58 .

10. Bennabi mentions the important roles played by Shaykh Salah bn Mohanna and Shaykh Abd al-Qadir al-Majawi in Discours sur les conditions de la Renaissance algérienne (Algiers: En-Nahda, 1949), 16. This book will be discussed later.

11. Mémoires, 109-10.

12. Abd al-Qadir (1807-1883) ranks as Algeria's greatest modern national hero. He fought the French in the 1830s and 1840s and created a veritable state in western Algeria. He surrendered in 1847 and was exiled. His resistance and noble character inspired Algerians and even earned the respect of the French. Bennabi highly respected Emir Khaled.

13. Mémoires, 110.

14. Fawzia Muhammad Bariun, "Malik Bennabi's Life and Theory of Civilization," Ph.D. diss., University of Michigan, 1988, 97-98.

15. Allan Christelow, "An Islamist Humanist in the 20th Century: Malik Bennabi," Maghreb Review 17, nos. 1-2 (1992), 72.

16. See Christelow, "An Islamist Humanist," 73, citing Mudhakkirat shadid al-qarn: Al-talib (Memories of a Witness of the Century: The Student) (Beirut: Dar al-Fikr, 1970), 68, and Mushkilat al-afkar fi-1-'alam al-islami (The Problem of Ideas in the Islamic World) (Cairo, 1971), 165, 188.

17. Malek Bennabi, Le phénomène coranique: Essai d’une théorie sur le Coran (Algiers: EnNahda, 1947), 9. This is the same audience that historian and nationalist Ahmed Tewfik al-Madani addressed in his Kitab al-Jaza’ir (Book of Algeria) (1931). Both men sought to instill a historical and religious consciousness within the youth. At this time, Bennabi wrote for La République Algérienne, the newspaper of the Ferhat Abbas's Union démocratique musulmane algérienne (UDMA). Bennabi particularly wanted to reach Ferhat's constituency. By that time, Abbas was no longer an assimilationist but a nationalist. Bennabi also wrote for Tewfik al-Madani's Jeune Musulman. He wrote in French and in Arabic in order to reach specific readers. For example, many Algerian elites could not read Arabic. Eventually, he translated some of his work in French into Arabic, which considerably widened his audience within the Arab world.

18. Le phénomène coranique, 9-10. See Edward Saïd, Orientalism (New York: Vintage, 1979).

19. Mohamed el-Tahir el-Mesawi, "Translator's Introduction: Contextualizing the Qur'anic Phenomenon," in Malik Bennabi, The Qur'anic Phenomenon: An Essay of a Theory on the Qur'an (Kuala Lampur: Islamic Book Trust, 2001), xvii. 
20. Ibid., xvi.

21. Muhammad bn Sa'i (Hamouda Bensaï) (1902-1999) was a student of the renowned French Orientalist Louis Massignon. (Bn Sa'i was studying the ideas of Islam's most renowned theologian, Abu Hamid al-Ghazali [1058-1111].) They apparently broke their relationship over the terrible Sétif Riots of 8 May 1945, which resulted in 15,000-20,000 indigène deaths. This event contributed to bn Sa'i's physical and emotional breakdown. Bn Sa'i also influenced Bennabi regarding Friedrich Nietzsche's thought. Allan Christelow wrote: "That Bennabi himself not only survived, but thrived through the chaotic and violent years of the nationalist movement, the revolution, and independence, attests to a great fortitude of character and sense of perspective" (Christelow, "An Islamist Humanist," 70-71). Asma Rashid also credits Khadija for her constant support of Bennabi ("Malek Bennabi: His Life," 11).

22. Christelow, "An Islamist Humanist," 75.

23. Bennabi, Discours sur les conditions, 13, 17-18.

24. Ibid., 18, 21. The Congrès was organized by Dr. Mohammed Salah Bendjelloul, a moderate activist, to mobilize support for the Blum-Viollette Bill, which sought to give approximately 10,000 to 20,000 indigènes French citizenship without the loss of Muslim status. The ulama participation in the Congrès, especially as secondary players, was unacceptable to Bennabi.

25. Ibid., 49-50.

26. Ibid., 22.

27. Ibid., 31 .

28. Bennabi viewed the development of civilization as a catalytic process involving three agents: man, land ("soil"), and time. He viewed "psycho-temporal" ideas, especially religion, as foundational. Regarding Muslim civilization, this psycho-temporal/spiritual stage's trajectory ended with the divisive Battle of Siffin in 659, and soon afterward the establishment of the Umayyad Caliphate. A second temporal/rational stage then appeared (as the civilization's "soul" flat-lines). After centuries, ending with the life and times of Ibn Khaldun (1332-1406), Muslim civilization became stagnant and began to decline toward an "instinctual primitive stage," an ancestral condition. See Discours sur les conditions, 33.

29. Malek Bennabi, Vocation de l'Islam (Paris: Seuil, 1954), 15-17.

30. Ibid., 31. The Almohad Empire (1147-1269) united the Maghrib. Scholarship was patronized and featured Ibn Rushd (1126-98) and Ibn Tufayl (1110-85).

31. Ibid., 56.

32. Ibid., 82-86.

33. Bennabi moved without his wife, who was severely afflicted by rheumatoid arthritis. He remained in close contact. He eventually took a second wife.

34. Malek Bennabi, L’Afro-Asiatisme: Conclusions sur la Conférence de Bandoeng (Cairo: Imprimerie Misr, 1956), 55. In the complementary Fikra Kumunwilath Islami (Idea of 
an Islamic Commonwealth) (Cairo: Al-Maktab al-Fanni lil-Nashr, 1960), Bennabi orients his transnational trope regarding the Muslim world. The projected "Commonwealth" aimed at social and economic cooperation rather than political integration, which posed obvious difficulties. (Bennabi was also probably influenced at this time by Egypt's [failing] efforts at political integration, namely the United Arab Republic linking Egypt with Syria.) In particular, see Bennabi's analyses (and the influence of L'Afro-Asiatisme) and diagrams of the Islamic world (Fikra, 29-39).

35. Christelow, "An Islamist Humanist," 74.

36. Jacques Waardenburg refers to the "complex of colonisabilité" in Islam: Historical, Social, and Political Perspectives (Berlin: Walter de Gruyter, 2002), 141.

37. Frantz Fanon, Wretched of the Earth, trans. Constance Farrington (New York: Grove Press, 1968), 61.

38. Ibid., 93.

39. Vocation, 85. Dating from the 1930s, Bennabi "tried his best, though with little success, to direct the attention of the Algerian students, whom he saw with concern riding the Messali [Hajj] bandwagon, to the basic problem of psychological and social transformation as an essential prerequisite for the formation of a polity" (Rashid, "Malek Bennabi: His Life," 16). Bennabi was profoundly impressed with Mahatma Mohandas Gandhi's approach to decolonization, which also seemed to end South Asian colonizability.

40. Frantz Fanon, Toward the African Revolution: Political Essays (New York: Grove Press, 1969), 33.

41. Discours sur les conditions, 51 .

42. Vocation, 17.

43. Wretched of the Earth, 36.

44. Ibid., 315.

45. Afro-asiatisme, 105.

46. Ibid., 345 .

47. Ibid., 240.

48. Wretched of the Earth, 203.

49. Discours sur les conditions, 54 .

50. L'Afro-Asiatisme, 103. He would soon write SOS Algérie (1957), which signaled Bennabi's apprehension regarding the nationalists' actions.

51. See Malek Bennabi, Pour changer l'Algérie (Algiers: Société d'Edition et de Communication, 1989).

52. Discours sur les conditions, 90 .

53. Vocation, 84 . 
54. Ibid., 85 .

55. Algerian Islamist parties have had a direct or indirect debt to Bennabi's thought. Yahia H. Zoubir views Bennabi as a democratic Islamist in his article "Algerian Islamists' Conception of Democracy," Arab Studies Quarterly 18, no. 3 (Summer 1996), 65-85. 